\title{
EFFECTS OF L-GLUTAMIC ACID AND PYRIDOXINE ON GLUTATHIONE DEPLETION AND LIPID PEROXIDATION GENERATED BY EPINEPHRINE-INDUCED STRESS IN RATS
}

\author{
N. O. SALYHA \\ Institute of Animal Biology, NAAS of Ukraine, Lviv; \\ e-mail:ynosyt@yahoo.com
}

The main goal of this research was to investigate and compare the protective effects of L-glutamic acid (L-Glu) alone and combined with Pyridoxine (L-Glu+Pyridoxine) for the purpose of suppression and mitigation of epinephrine-induced stress in rats. This study outlines possible links between changes of reduced glutathione (GSH) level, antioxidant enzymes activity and content of the lipid peroxidation products after administration of the above-mentioned substances and under the action of stress in various tissues of rats. The obtained results suggest that the GSH level was significantly inhibited by stress in all investigated tissues (except kidneys). We have shown that under the stress, activities of glutathione-associated enzymes were changed (mainly decreased) in all investigated tissues. In rats, which additionally received L-Glu and L-Glu+Pyridoxine, much less changes or lack of changes in studied parameters were observed. The content of lipid peroxidation products (lipid peroxides $(\mathrm{LOOH})$ and thiobarbituric acid reactive substances (TBARS)) in myocardium, liver and kidney tissues of experimental groups under the stress conditions were significantly higher compared to the control. While in experimental groups that received L-Glu and L-Glu+Pyridoxine $\mathrm{LOOH}$ content in the kidney, spleen and liver and TBARS content in the spleen, liver and myocardium were almost at the level of control values. These results indicate that L-Glu and L-Glu+Pyridoxine can mitigate and suppress epinephrine-induced stress in rats.

Ke ywords: L-glutamic acid; Pyridoxine, antioxidant enzymes; reduce glutathione; oxidative stress; rats.

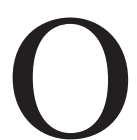

xidative stress - an imbalance in prooxidant/antioxidant homeostasis has been implicated in response to acute stress or other factors and associated with the initiation and progression of a variety of human diseases [1-4]. Oxidative stress is accompanied by the generation of reactive oxygen species (ROS) [5, 6]. To protect against oxidative damage all aerobic organisms use the antioxidant defence system. This system includes enzymatic and nonenzymatic antioxidants and takes an active part in blocking noxious effects of ROS. When ROS production overwhelms the intrinsic antioxidant defences, it leads to suppression of antioxidant system which is manifested in the depletion of GSH and GSH-related enzymes. ROS can cause damage to biological molecules, leading to the loss of function and even cell death [7-9].

In our investigations we studied the effects of L-Glu and L-Glu+Pyridoxine in order to minimize and mitigate the effects of oxidative stress. L-Glu has a pronounced antioxidant and membrane-stabilizing effect. During the stress conditions and diseases the organism requires the large number of L-Glu, which plays a major role in nitrogen metabolism, participates in protein and carbohydrate metabolism, stimulates oxidative processes, increases the body's resistance to hypoxia, normalizes metabolism and manifests hepatoprotective effect [10-12]. Choosing this amino acid we are guided by that fact that LGlu is a part of GSH and is one of the main factors that determines its synthesis. GSH has antioxidant and detoxification properties and takes active part in redox processes. GSH plays a critical role in cellular defences against oxidative stress, so regulation of GSH synthetic capacity, especially, in depletion conditions is an important target in the treatment of many disorders and has received much attention [8, 13-17]. Pyridoxine has a central role in the metabo-

(C) 2018 Salyha N.O. This is an open-access article distributed under the terms of the Creative Commons Attribution License, which permits unrestricted use, distribution, and reproduction in any medium, provided the original author and source are credited. 
lism of amino acids, participates in protein synthesis. Deficiency of Pyridoxine leads to a change in amino acids metabolism, in particular, L-Glu.

With regard to the above, the aim of our study was to investigate and compare the effect of L-Glu and L-Glu in combination with Pyridoxine on the glutathione system indicators and the content of lipid peroxidation products in rats under the action of experimental stress.

\section{Materials and Methods}

Studies were conducted on albino Wistar rats (males) weighing 200-220 g. They were housed in cages under standardized laboratory conditions with a 12-h light/12-h dark cycle. All rats were allowed free access to a standard rodent diet and water ad libitum. After 1 week of acclimation rats were divided into 4 groups (three experimental and one control) of 10 animals per group. Duration of the study period was 24 hours. Animals from the first (epinephrine), second (L-Glu) and third (L-Glu+Pyridoxine) experimental groups received epinephrine intraperitoneally in a dose $2 \mathrm{mg} / \mathrm{kg}$. After that rats from the second experimental group additionally received intraperitoneally aqueous solution of L-Glu in a dose $750 \mathrm{mg} / \mathrm{kg}$; rats from the third group - L-Glu (750 mg/kg) and Pyridoxine (Vitamin $\mathrm{B}_{6}$ ) in a dose $0.430 \mathrm{mg} / \mathrm{kg}$. Doses of L-Glu and Pyridoxine have been chosen based on their most effective antioxidant properties that were found in our previous exploratory research and literary data analysis [18-20]. Rats of the control group were administered the appropriate amount of saline. At the end of the experimental period, rats were anesthetized by ether and sacrificed. The liver, brain, kidney, myocardium, spleen, lung tissues were rapidly excised and stored at $-80{ }^{\circ} \mathrm{C}$ for further analysis.

All procedures were conducted according to the European Convention for the Protection of Vertebrate Animals Used for Experimental and Other Scientific Purposes (Strasbourg, 1986) and General Ethical Principles of Experiments Using Animals (First National Congress of Bioethics, Kyiv, 2001) in accordance with current legislation on animal experimentation in Ukraine.

One gram of the liver, brain, kidney, myocardium, spleen, lung tissues was homogenized in 9-ml tris $\mathrm{HCl}$ buffer $\mathrm{pH}$ 7.4. The homogenate was then centrifuged at $15000 \mathrm{~g}$ for $15 \mathrm{~min}$ at $4{ }^{\circ} \mathrm{C}$. The supernatants were used to determine the activity of antioxidant enzymes and lipid peroxidation products and glutathione content.
GPx (glutathione hydrogen-peroxide oxidoreductase, EC 1.11.1.9) activity was checked by measuring the tempo of GSH oxidation before and after incubation with tertiary butyl hydroperoxide as described earlier [10]. The colour reaction is based on the interaction of SH-groups with the 5,5-dytiobis2-nitrobenzoic acid (DTNBA), resulting in the formation of colored product - dinitrophenyl anion. Quantity of the latter is directly proportional to the number of SH-groups that have reacted with DTNBA. Enzyme activity was expressed as nmol GSH/min.mg of protein.

GR (glutathione $\mathrm{NADP}^{+}$oxidoreductase, EC 1.6.4.2) activity was measured as described earlier [10]. This method is based on the catalytic NADPH-dependent reduction of the oxidized form of glutathione. The reaction intensity can be assessed by the tempo of decrease of the extinction on the wavelength of NADPH maximum absorption (340 nm). GR activity was calculated using molar absorption ratio for NADPH at a wavelength of $340 \mathrm{~nm}$. The enzyme activity was expressed in $\mu \mathrm{mol}$ $\mathrm{NADPH} / \mathrm{min} \cdot \mathrm{mg}$ of protein.

GSH content was determined by the level of thionitrophenyl anion formation as described earlier [10]. This colour reaction is based on the interaction between SH-groups of GSH and DTNBA. GSH content was measured using the calibration graph and expressed in mmol GSH per gram of tissue.

The content of lipid hydroperoxides ( $\mathrm{LOOH})$ in tissues was determined as described by [21]. Absorption measurements were performed after the addition of ammonium thiocyanate at $\lambda 480 \mathrm{~nm}$. The control test was set as experimental, but instead of the tissue homogenate, an appropriate amount of bidistilled water was added. The content of lipid hydroperoxides was calculated by the difference between experimental and control values, and expressed in standard units per 1 gram of tissue.

The concentration of TBARS, characterizing the rate of lipid peroxidation based on the reaction between malondialdehyde (MDA) and thiobarbituric acid (TBA), occurring at high temperature and in acidic environment, and forming the colored complex of one MDA and two TBA molecules were measured as described by [21]. The values are expressed as nmol MDA/g tissue.

The experimental data were processed by variation statistics methods using the program OriginPro 8. Student's $t$-test was used to determine the likely differences between the means of the sam- 
ples. In all cases, reliable differences were considered by $P$ value under 5\% $(P<0.05)$.

\section{Results and Discussion}

The glutathione system plays a key role in protecting a cell from oxidative stress. The glutathione system includes glutathione, glutathione reductase, glutathione peroxidases, and glutathione S-transferases. [22]. These enzymes are involved in glutathione redox cycle and are important for the antioxidant stress response. Glutathione serves as a substrate for regulating most of the oxidative processes in cell. The reduced form of glutathione is also an essential cofactor in different cellular functions. Our results have showed (Fig. 1) that the GSH content was significantly lower in animals that were exposed to experimental stress in all investigated tissues, except kidneys. The GSH content in rats of the first experimental group which received only epinephrine was lower in the spleen tissues 1.7 times, in the liver -1.9 times, in the brain -4.3 times, in the lungs -3.3 times, in the myocardium almost 2.5 times compared to control animals. The GSH level decrease may be due to the intensive use of GSH in biochemical processes occurring in the body under the oxidative stress [23, 24]. GSH level reached, and sometimes exceeded the control values in animals that received L-Glu and L-Glu+Pyridoxine. Since the main part of GSH is synthesized in the liver (about
$90 \%$ ), from where it is transported to various organs and tissues. Maintaining the physiological level of this antioxidant is very important. It is known that the failures of this process in the organism result in systemic inter-organ disturbances of glutathione homeostasis [17]. It can be assumed that the increase of GSH level was due to its "de novo" synthesis involving the enzyme $\gamma$-glutamyl-cysteine synthase, and probably, the substrate for this could be L-Glu. It should be noted that the level of this tripeptide was close to the control values in the brain tissues of the third experimental group (L-Glu+Pyridoxine) and in the myocardium of the second (L-Glu) and third experimental groups (L-Glu+Pyridoxine). The GSH content in lung tissues was significantly lower in animals of all experimental groups compared to control. The GSH level of the second (L-Glu) and third (L-Glu+Pyridoxine) experimental groups in liver tissues was 1.9 and 2.1 times higher; in lungs 2.1 and 1.7 times; in myocardium 2.2 and 3.1 times; in brain 1.5 and 3.9 times compared to the first experimental group which received epinephrine.

GSH has been involved in cell protection from the harmful effect of excess oxidative stress, both directly and as a substrate of glutathione peroxidases. As the results of our research antioxidant enzyme, GPx, showed pronounced alterations too. The activity of GPx was significantly lower $(50 \%)$ in the kidney of the first experimental group that

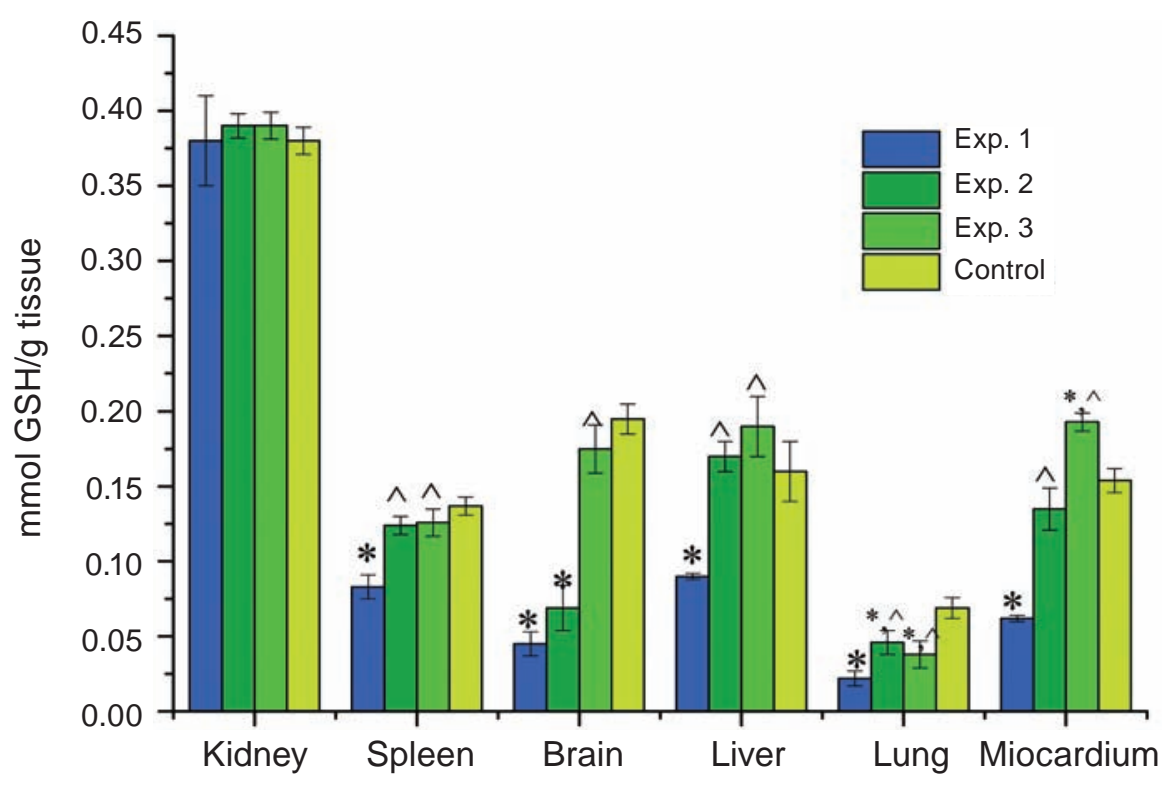

Fig. 1. Effect of L-Glu and L-Glu+Pyridoxine on the GSH content under the action of epinephrine-induced stress. Data are means \pm SEM. *Significantly different from the respective control group with $P<0.05 ;{ }^{\wedge}$ significantly different from the respective first experimental group with $P<0.05$ 
received only epinephrine compared to the control (Fig. 2). We also observed a significantly higher activities of kidney GPx of the second (L-Glu) (74\%) and third (L-Glu+Pyridoxine) (50\%) experimental groups compared to epinephrine administration experimental group. It should be noted that the GPx activity has almost reached the level of control values in liver tissue of the second (L-Glu) and third (L-Glu+Pyridoxine) experimental groups. By contrast, the liver GPx activity of the first experimental group that received only epinephrine significantly decreased (60\%), compared to the control. The GPx activity was significantly higher (more than 2 times) in the spleen tissues of epinephrine experimental group compared to control, second (L-Glu) and third (L-Glu+Pyridoxine) experimental groups. We found that GPx activity was lower respectively: in the lung tissue of epinephrine (1.5 times), L-Glu (1.6 times) and L-Glu+Pyridoxine (1.5 times) experimental groups and myocardium tissue of only epinephrine (1.6 times) and L-Glu+Pyridoxine (1.7 times) experimental groups compared to control. It is possible that the decrease in GPx activity in the above tissues is due to the accumulation of lipoperoxidation products. The experimental conditions did not affect the GPx activities in the brain.

The functioning of the GPx is closely related to the activity of GR. These two enzymes form a sin- gle antiperoxide system that provides a glutathione redox cycle. The GPx uses GSH as a substrate that converts to oxidized glutathione, which is further restored in the glutathionereductase reaction. GR activity (Fig. 3) in our studies was higher in the kidney tissues of all experimental groups compared to control, but probably differences were only in animals of the first (only epinephrine) and second (L-Glu) groups (by 58 and 50\%, respectively). GR activities decreased by $67 \%$ in the liver, $36 \%$ in the myocardium and $60 \%$ in the lung of first experimental group exposed to stress by epinephrine. Despite that the GR activity in the liver of the second ( $\mathrm{L}$ Glu) and third (L-Glu+Pyridoxine) experimental groups almost reached the control values and was higher, respectively, by 58 and 34\% compared to the animals of the first experimental group that received only epinephrine. The brain GR activity decreased in the first (only epineprine) and second (L-Glu) experimental groups, respectively, 2.3 and 1.3 times compared to control. It is worth noting that brain GR activity was 1.4 and 2.5 times higher in animals of the second (L-Glu) and third (L-Glu+Pyridoxine) groups compared to the first experimental one, animals from which were only stressed. This is important given that the brain is particularly vulnerable to oxidative damage due to its high oxygen consumption, high content of oxidisable polyunsaturated fatty

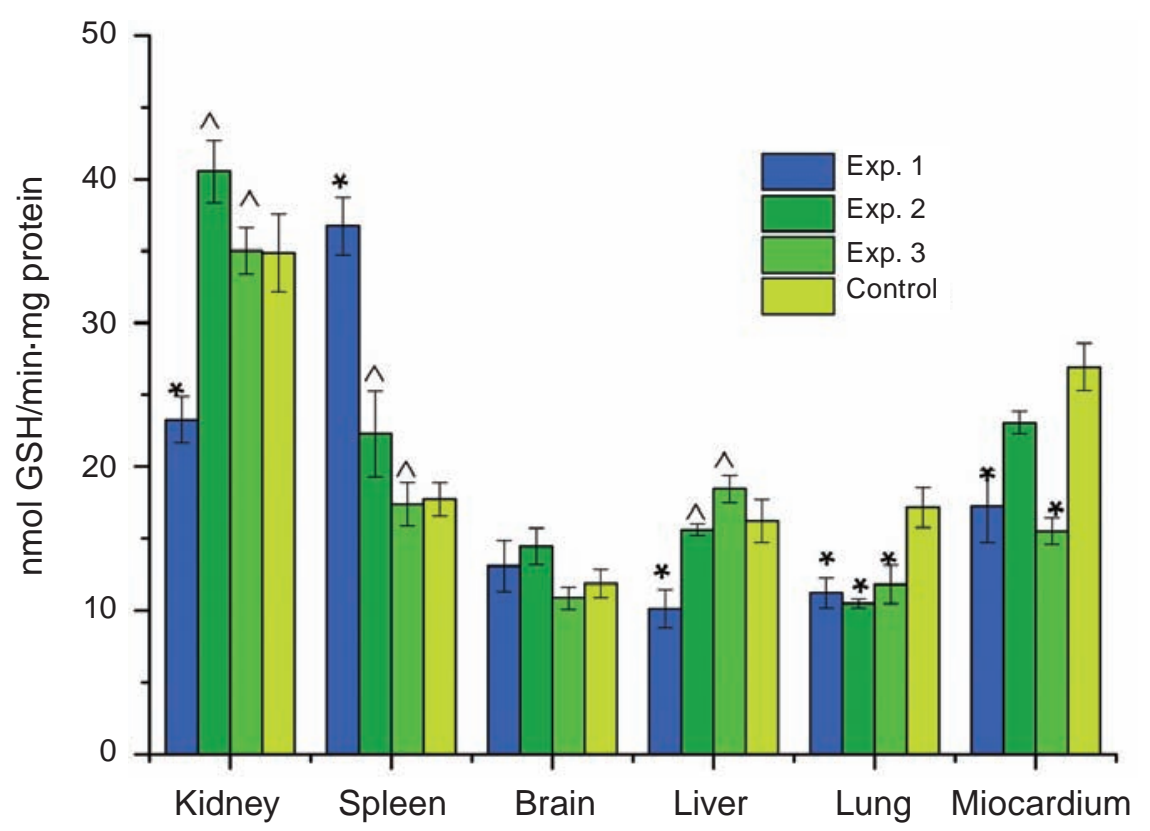

Fig. 2. Effect of L-Glu and L-Glu+Pyridoxine on the GPx activity under the action of epinephrine-induced stress. Data are means \pm SEM. *Significantly different from the respective control group with $P<0.05$; ${ }^{\text {sig- }}$ nificantly different from the respective first experimental group with $P<0.05$ 


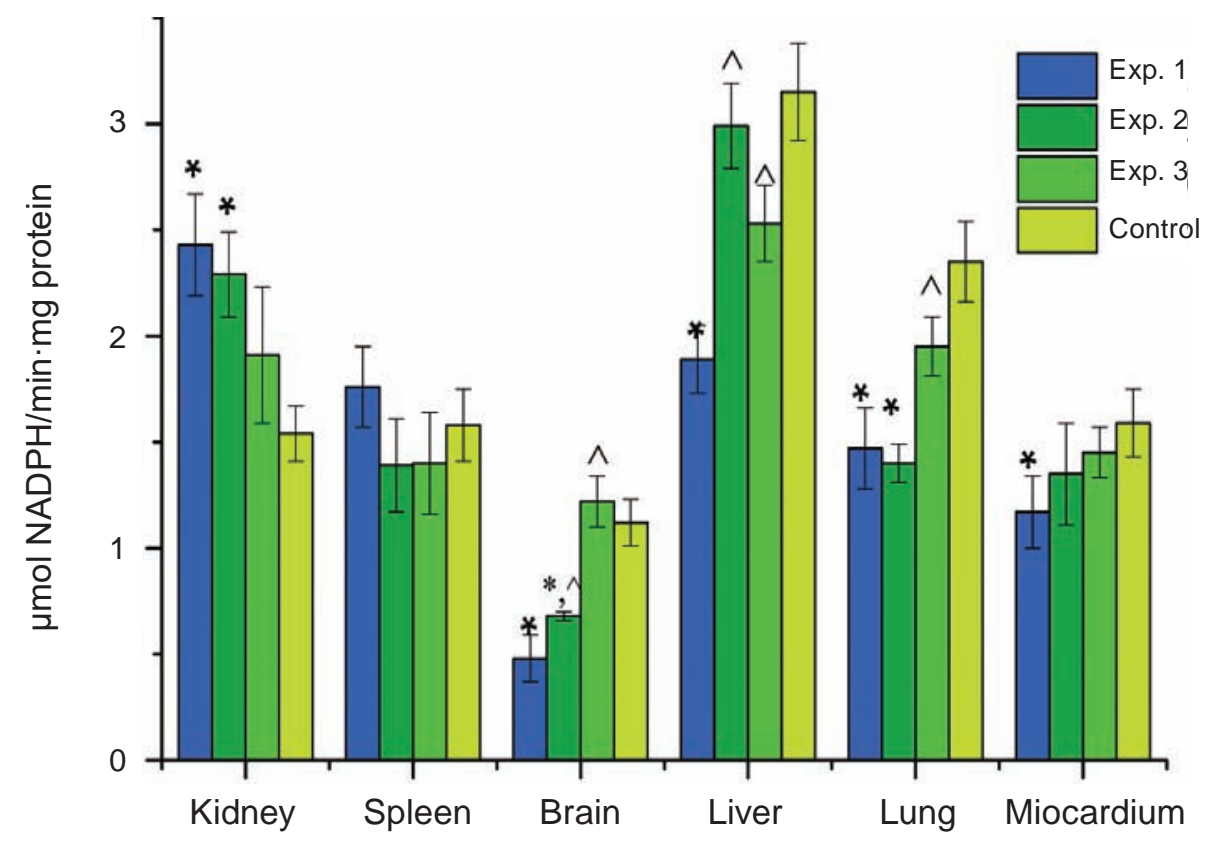

Fig. 3. Effect of L-Glu and L-Glu+Pyridoxine on the GR activity under the action of epinephrine-induced stress. Data are means \pm SEM. *Significantly different from the respective control group with $P<0.05$; ${ }^{\text {sig- }}$ nificantly different from the respective first experimental group with $P<0.05$

acids, weakly antioxidative systems and the presence of redox-active metals $[25,26]$.

The glutathione system is involved in the regulation of lipid peroxidation. GSH depletion leads to the intensification of lipid peroxidation. The results of our research (Fig. 4) showed that LOOH content in the first experimental group that received only epinephrine significantly increased in kidney tissues (51\%), spleen (32\%), liver (93\%), lung (52\%), and myocardium (76\%) compared to the control. In contrast, the $\mathrm{LOOH}$ content in the animals of the second and third experimental groups, which additionally received L-Glu and L-Glu+Pyridoxine reached the control values or even slightly exceeded them in the tissues of the kidneys, spleen and liver. A decreased $\mathrm{LOOH}$ content was found in the animals of the second (L-Glu) and third (L-Glu+Pyridoxine) experimental groups, respectively: in the kidney by 30 and $41 \%$; in the spleen by 47 and $29 \%$; in the liver by 54 and $72 \%$ compared to the first experimental group. $\mathrm{LOOH}$ content in the lung tissue was higher in all experimental groups of rats.

Hydroxyl radical initiates ROS and removes hydrogen atom, thus producing lipid radical further converted into diene conjugate. As shown in Fig. 5 TBARS content of the experimental group that received only epinephrine was significantly higher in tissues of the kidney (87\%), liver (55\%), myocardium
(40\%) compared to control. In contrast, TBARS content in the liver and myocardium tissues of the second (L-Glu) and third (L-Glu+Pyridoxine) experimental groups was at the level of control values. Analyzing these data, it can be assumed that additional consumption of L-Glu and Pyridoxine has an inhibitory effect on the synthesis of TBARS. The additional administration of L-Glu and LGlu+Pyridoxine led to the suppression of oxidative processes in the above tissues of the second and third experimental groups, which was manifested in lowering of the lipid peroxidation products.

In this study, we tried to examine relationships between changes of glutathione system indicators and content of lipid peroxidation products after administration of the L-Glu and L-Glu+Pyridoxine and under the action of stress. Reducing the activity of antioxidant enzymes in animals of the experimental group that received only epinephrine may be due to compensatory reactions occurring in the body in response to the effect of experimental stress. Against the background of the decrease in the activity of key enzymes in the rats of the first experimental group, the animals of two other experimental groups, which additionally received, respectively, L-Glu+Pyridoxine differed favourably. The activity of the above mentioned enzymes in these groups were closer to the values in the control group 


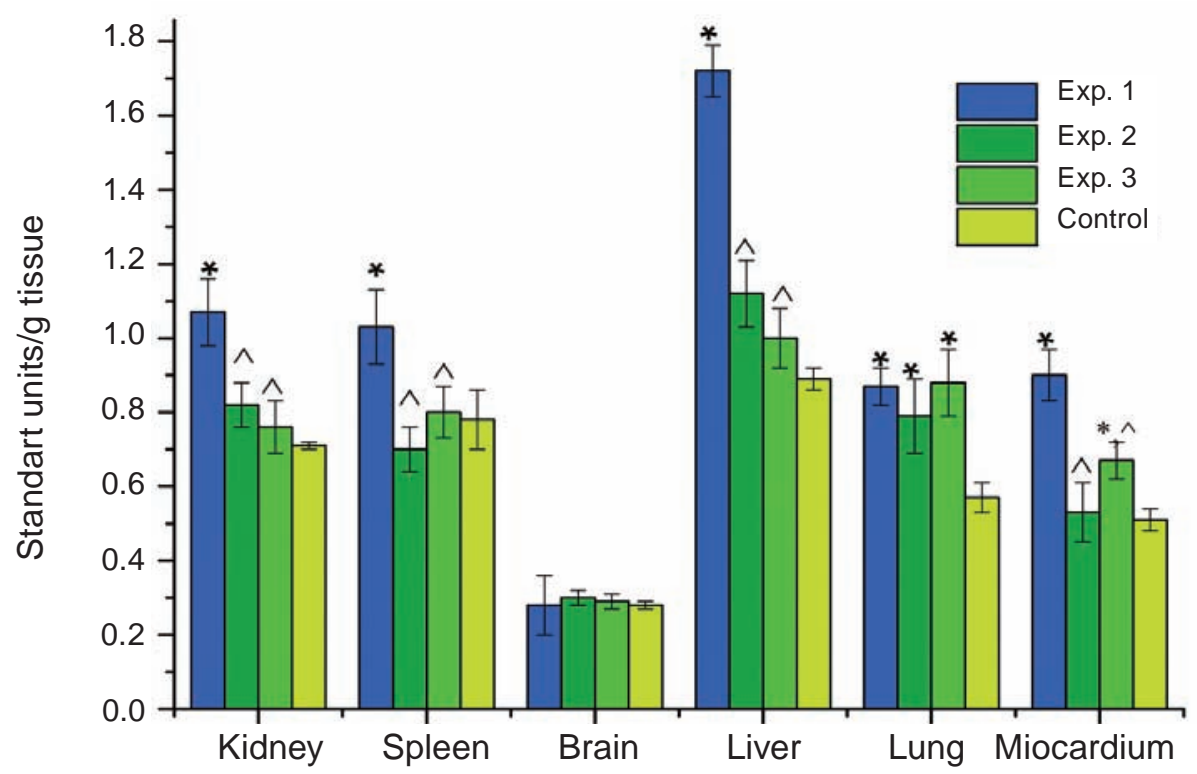

Fig. 4. Effect of L-Glu and L-Glu+Pyridoxine on the LOOH content under the action of epinephrine-induced stress. Data are means \pm SEM. *Significantly different from the respective control group with $P<0.05$; ${ }^{\text {sig- }}$ nificantly different from the respective first experimental group with $P<0.05$

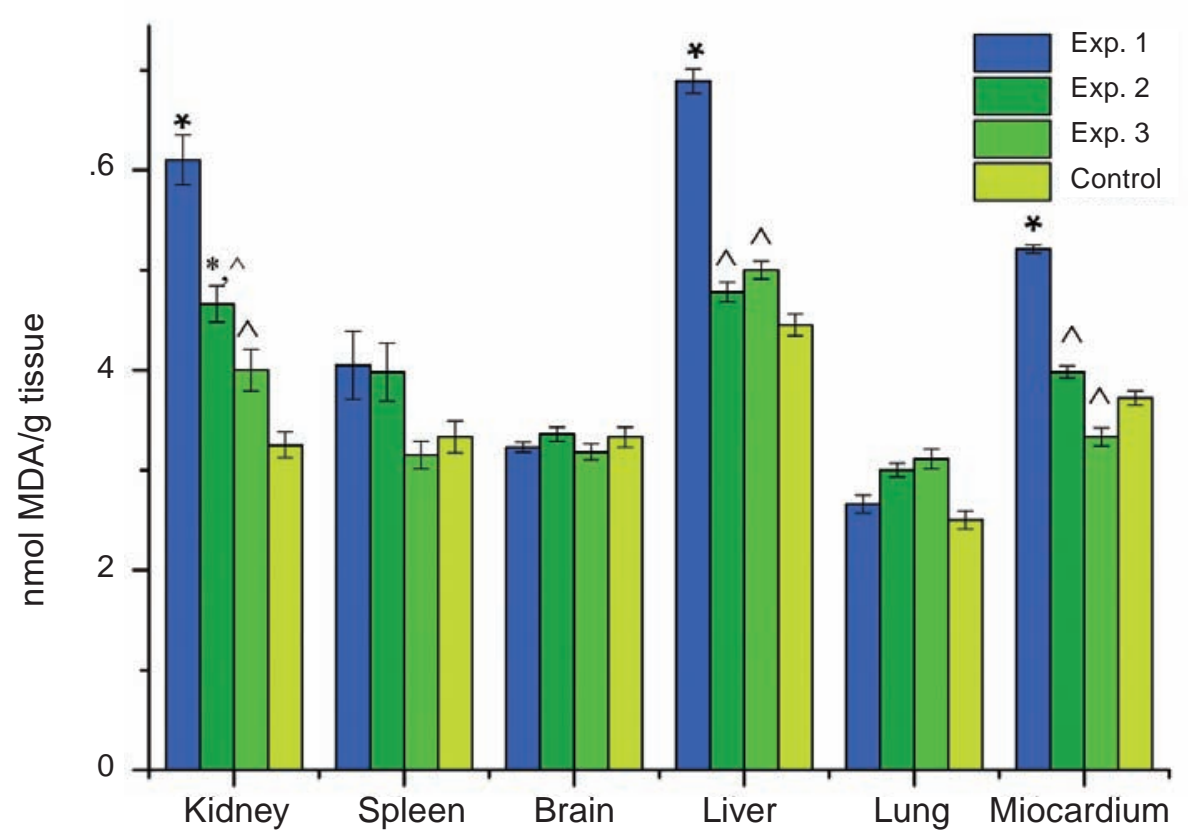

Fig. 5. Effect of L-Glu and L-Glu+Pyridoxine on the TBARS content under the action of epinephrine-induced stress. Data are means \pm SEM. *Significantly different from the respective control group with $P<0.05$; $\wedge_{\text {sig- }}$ nificantly different from the respective first experimental group with $P<0.05$

of animals. This may be due to the antioxidant and membrane-stabilizing properties of the L-Glu used in the studies.

The study of mechanisms for regulating GSH level, especially in conditions conducive to its ex- haustion, is a very important problem. Because prolonged activation of glutathione-associated enzymes is possible by maintenance of a sufficiently high intracellular levels of GSH, which acts as a substrate of reactions. Analyzing the results, we can 
surmise that the intracellular GSH content in animals that additionally received amino acids L-Glu, L-Glu+Pyridoxine is provided not only by the regeneration of oxidized glutathione under the action of GR and NADPH $\left(\mathrm{H}^{+}\right)$. On this basis, it would be logical to assume the growth of GSH content in the above groups is due to the "de novo" synthesis, involving $\gamma$-glutamyl cysteine synthase, and probably the substrate for this is L-Glu. This is clearly demonstrated in the liver tissue, where the synthesis of this tripeptide is mainly carried out.

Thus, it was found that administering of epinephrine at a dose $(2 \mathrm{mg} / \mathrm{kg})$ resulted in a decrease in the GSH content, the activity of glutathione-associated enzymes, and an increase in the content of lipid peroxidation products in the most investigated tissues. Our results showed that the additional administration of L-Glu, L-Glu+Pyridoxine leads to changes in the activity of glutathione antioxidant system and the intensity of lipid peroxidation, namely the increase of GSH, GPx, GR activities and the decrease of TBARS and LOOH contents. The use of the L-Glu and L-Glu+Pyridoxine helps the organism to reach the control values by some indicators or at least get closer to them, than animals which did not receive the above mentioned substances. These studies can be used in further work to find effective substances for mitigation and inhibiting of oxidative stress.

\section{ВПЛИВ L-ГЛУТАМІНОВОї КИСЛОТИ І ПІРИДОКСИНУ НА ВИСНАЖЕННЯ РІВНЯ ГЛУТАТІОНУ І ПЕРОКСИДНЕ ОКИСЛЕННЯ ЛІПІДІВ, СПРИЧИНЕНІ ЕПІНЕФРИНІНДУКОВАНИМ СТРЕСОМ УЩУ РІВ}

\section{H. О. Салига}

\section{Інститут біології тварин НААН України, Львів; e-mail: ynosyt@yahoo.com}

Метою роботи було дослідити і порівняти захисні ефекти L-глутамінової кислоти (L-Glu) як окремо, так і у поєднанні з піридоксином (L-Glu+Pyridoxine) за дії епінефриніндукованого стресу в щурів. Окреслено можливі зв'язки між змінами рівня відновленого глутатіону (GSH), активністю антиоксидантних ензимів і вмістом продуктів пероксидного окислення після введення вищезгаданих речовин та дії стресу в різних тканинах щурів. Показано, що внаслідок стресу вміст GSH істотно знижувався в усіх досліджуваних тканинах (за винятком нирок), в усіх тканинах також знижувалась активність глутатіонзалежних ензимів. У тварин, що додатково отримували L-Glu i L-Glu+Pyridoxine набагато менше змінювались досліджувані показники або не змінювались взагалі. Вміст продуктів пероксидного окислення (гідрорероксиди ліпідів (LOOH) і ТБК-активні продукти (TBARS)) у тканинах міокарда, печінки та нирок у тварин, що зазнали стресу, був вірогідно вищим порівняно 3 контролем, тоді як у тварин, що додатково отримували L-Glu i L-Glu+Pyridoxine, вміст LOOH у тканинах нирок, селезінки та печінки i вміст TBARS у тканинах селезінки, печінки та міокарда був майже на рівні контрольних значень. Одержані результати свідчать про те, що L-Glu i L-Glu+Pyridoxine можуть пом'якшувати та пригнічувати гострий стрес у щурів.

К л ю ч о в і с лова: L-глутамінова кислота, піридоксин, антиоксидантні ензими, відновлений глутатіон, оксидаційний стрес, щури.

\section{ВЛИЯНИЕ L-ГЛУТАМИНОВОЙ КИСЛОТЫ И ПИРИДОКСИНА НА ИСТОЩЕНИЕ УРОВНЯ ГЛУТАТИОНА И ПЕРОКСИДНОЕ ОКИСЛЕНИЕ ЛИПИДОВ, ВЫЗВАННЫЕ ЭПИНЕФРИН- ИНДУЦИРОВАННЫМ СТРЕССОМ У КРЫС}

\section{Н. О. Сальга}

\author{
Институт биологии животных \\ НААН Украины, Львов; \\ e-mail: ynosyt@yahoo.com
}

Целью работы было исследовать и сравнить защитные эффекты L-глутаминовой кислоты (L-Glu) как отдельно, так и в сочетании с пиридоксином (L-Glu+Pyridoxine) при эпинефрининдуцированном стрессе у крыс. Определены возможные связи между изменениями уровня восстановленного глутатиона (GSH), активностью антиоксидантных энзимов и содержанием продуктов пероксидного окисления после введения вышеупомянутых веществ и действия эпинефрина в различных тканях крыс. Показано, что при введении эпинефрина содержание GSH 
существенно снизилось во всех исследуемых тканях (за исключением почек), также во всех тканях активность глутатионзависимых энзимов снижалась. У животных, дополнительно получавших L-Glu и L-Glu+Pyridoxine гораздо меньше изменялись исследуемые показатели или изменения отсутствовали вообще. Содержание продуктов пероксидного окисления (гидропероксиды липидов (LOOH) и ТБК-активные продукты (TBARS)) в тканях миокарда, печени и почек у животных, которые подвергались только действию стресса, было достоверно выше по сравнению с контролем, тогда как у животных, дополнительно получавших L-Glu и L-Glu+ Pyridoxine, содержание LOOH в тканях почек, селезенки и печени и содержание TBARS в тканях селезенки, печени и миокарда было почти на уровне контрольных значений. Полученные результаты свидетельствуют о том, что L-Glu и L-Glu+Pyridoxine могут смягчать и подавлять острый стресс у крыс.

К л ю ч в в е с ло в а: L-глутаминовая кислота, пиридоксин, антиоксидантные энзимы, восстановленный глутатион, оксидативный стресс, крысы.

\section{References}

1. Sies H, Berndt C, Jones DP. Oxidative Stress. Annu Rev Biochem. 2017; 86(1): 715-748.

2. Schiavone S, Jaquet V, Trabace L, Krause KH. Severe life stress and oxidative stress in the brain: from animal models to human pathology. Antioxid Redox Signal. 2013; 18(12): 1475-1490.

3. Burton GJ, Jauniaux E. Oxidative stress. Best Pract Res Clin Obstet Gynaecol. 2011; 25(3): 287-299.

4. Lobo V, Patil A, Phatak A, Chandra N. Free radicals, antioxidants and functional foods: Impact on human health. Pharmacogn Rev. 2010; 4(8): 118-126.

5. Circu ML, Aw TY. Reactive oxygen species, cellular redox systems, and apoptosis. Free Radic Biol Med. 2010; 48(6): 749-762.

6. Giorgio M, Trinei M, Migliaccio E, Pelicci PG. Hydrogen peroxide: a metabolic by-product or a common mediator of ageing signals? Nat Rev Mol Cell Biol. 2007; 8(9): 722-728.

7. Valko M, Leibfritz D, Moncol J, Cronin MT, Mazur M, Telser J. Free radicals and antioxidants in normal physiological functions and human disease. Int J Biochem Cell Biol. 2007; 39(1): 44-84.

8. Franco R, Cidlowski JA. Apoptosis and glutathione: beyond an antioxidant. Cell Death Differ. 2009; 16(10): 1303-1314.

9. Sies H. Hydrogen peroxide as a central redox signaling molecule in physiological oxidative stress: Oxidative eustress. Redox Biol. 2017; 11: 613-619.

10. Salyha NO. Activity of the glutathione system of antioxidant defense in rats under the action of L-glutamic acid. Ukr Biokhim Zhurn. 2013; 85(4): 40-47. (In Ukrainian).

11. Liu G, Wu XJ, Jia G, Zhao H, Chen X, Wu C, Wang J. Effects of glutamine against oxidative stress in the metabolome of rats-new insight. RSC Advances. 2016; 6(78): 74515-74524.

12. Brosnan JT, Brosnan ME. Glutamate: a truly functional amino acid. Amino Acids. 2013; 45(3): 413-418.

13. Schulz JB, Lindenau J, Seyfried J, Dichgans J. Glutathione, oxidative stress and neurodegeneration. Eur J Biochem. 2000; 267(16): 4904-4911.

14. Aoyama K, Nakaki T. Glutathione in Cellular Redox Homeostasis: Association with the Excitatory Amino Acid Carrier 1 (EAAC1). Molecules. 2015; 20(5): 8742-8758.

15. Lu SC. Glutathione synthesis. Biochim Biophys Acta. 2013; 1830(5): 3143-3153.

16. Yu M, Liu Y, Duan Y, Chen Y, Han J, Sun L, Yang $\mathrm{X}$. Inhibition of glutathione production by L-S,R-buthionine sulfoximine activates hepatic ascorbate synthesis - A unique anti-oxidative stress mechanism in mice. Biochem Biophys Res Commun. 2017; 484(1): 56-63.

17. Griffith OW. Biologic and pharmacologic regulation of mammalian glutathione synthesis. Free Radic Biol Med. 1999; 27(9-10): 922-935.

18. Salyha NO. Functioning of antioxidant system of rats at the action of L-glutamic acid and cysteine at experimental stress. J V.N.Karazin Kharkiv Nat Univ Ser Biol. 2013; 17(1056): 21-25.

19. Garlick PJ. Assessment of the safety of glutamine and other amino acids. J Nutr. 2001; 131(9 Suppl): 2556S-2561S.

20. Handbook of Nuclear, Biological, and Chemical Agent Exposures. Eds. Leikin JB, McFee R., Kerscher R. CRC Press, 2007. 752 p.

21. Rosalovsky VP, Grabovska SV, Salyha YuT. Changes in glutathione system and lipid 
peroxidation in rat blood during the first hour after chlorpyrifos exposure. Ukr Biochem $\mathrm{J}$. 2015; 87(5): 124-132.

22. Aquilano K, Baldelli S, Ciriolo MR. Glutathione: new roles in redox signaling for an old antioxidant. Front Pharmacol. 2014; 5: 196.

23. Ballatori N, Krance SM, Notenboom S, Shi S, Tieu K, Hammond CL. Glutathione dysregulation and the etiology and progression of human diseases. Biol Chem. 2009; 390(3): 191-214.
24. Marí M, Morales A, Colell A, García-Ruiz C, Fernández-Checa JC. Mitochondrial glutathione, a key survival antioxidant. Antioxid Redox Signal. 2009; 11(11): 2685-2700.

25. Wang X, Michaelis EK. Selective neuronal vulnerability to oxidative stress in the brain. Front Aging Neurosci. 2010; 2: 12.

26. Li J, O W, Li W, Jiang ZG1, Ghanbari HA. Oxidative stress and neurodegenerative disorders. Int J Mol Sci. 2013; 14(12): 2443824475.

Received 22.02.2018 